\title{
Teaching Picturebooks in First Year Literature Courses
}

\author{
Enseñar con álbumes ilustrados en primeros cursos de literatura
}

Ensenyar amb àlbums il·lustrats a primers cursos de literatura

\author{
Danielle A. Morris-O'Connor. University of Alberta, Canada. \\ doconnor@ualberta.ca \\ https://orcid.org/0000-0002-8739-3251
}

\begin{abstract}
In many universities, first year literature courses are required for students in a wide variety of programs, including arts and sciences. These courses are generally focused on teaching transferable skills and strategies, such as critical analysis, essay writing, and research. This article argues that picturebooks are an exceptional teaching tool for these broadly focused first-year courses, because they quickly engage students as learners, encourage participation, and open students to new approaches of critically reading texts while challenging their assumptions and personal biases about children's literature. Examples of picturebooks, secondary sources, class discussion, and group work activities used in first year literature courses are shared, along with students' responses to these approaches. The article ends with an explanation of a short, low-stakes assignment that instructors can assign students to help build essential skills with picturebooks, and exercises to do around picturebooks to work on critical thinking skills. Picturebooks are often perceived as being simple and only for children, but many picturebooks are layered texts that make great teaching tools for any literature course.
\end{abstract}

Keywords: first-year undergraduates, picturebooks, student engagement, literature course, transferable skills/strategies

\section{Resumen}

En muchas universidades, los primeros cursos de literatura son un requisito para el estudiantado de una gran variedad de programas, incluyendo las artes y las ciencias. Estos cursos, generalmente, se centran en enseñar habilidades y estrategias transferibles como el análisis crítico, la escritura de ensayos y la investigación. Este artículo argumenta que los álbumes ilustrados son una herramienta excepcional de enseñanza para estos cursos enfocados de manera muy amplia ya que motivan al alumnado como aprendices, motivan la participación y abren este alumnado a nuevos enfoques a la lectura crítica de textos al tiempo que plantean un reto a sus asunciones y sesgos personales sobre la literatura infantil. Se compartieron ejemplos de álbumes ilustrados, fuentes secundarias, discusiones de aula y actividades de trabajo en grupo que se utilizaron en las clases de literatura para primeros cursos junto con las respuestas del alumnado a estos planteamientos. El artículo acaba con la explicación de una tarea corta, de bajo riesgo, que el profesorado puede pedir al alumnado para ayudarlo a construir habilidades básicas con álbumes y ejercicios para hacer sobre estos para trabajar con habilidades de pensamiento crítico. Los álbumes ilustrados se perciben a menudo como 
simples y dirigidos a niños y niñas, pero muchos álbumes tienen diferentes capas que los convierten en herramientas magníficas para cualquier curso de literatura.

Palabras clave: alumnado de primer curso de carrera, álbumes ilustrados, motivación del alumnado, curso de literatura, habilidades/estrategias transferibles

Resum

A moltes universitats, els primers cursos de literatura són un requisit per a estudiantat de una gran varietat de programes, incloent-hi arts i ciències. Aquests cursos, generalment, se centren a ensenyar habilitats i estratègies transferibles com l'anàlisi crítica, l'escriptura d'assajos i la recerca. Aquest article argumenta que els àlbums il·lustrats són una eina excepcional d'ensenyament per aquests cursos enfocats de forma molt àmplia ja que motiven l'alumnat com a aprenents, motiven la participació i obrin aquest l'alumnat a nous acostaments a la lectura crítica de textos mentre plantegen un repte a les seues assumpcions i biaixos personals sobre la literatura infantil. Es van compartir exemples d'àlbums il-lustrats, fonts secundàries, discussions d'aula i activitats de treball en grup que s'utilitzaren a les classes de literatura per a primers cursos, junt amb les respostes de l'alumnat a aquests enfocaments. L'article acaba amb l'explicació d'una tasca curta, de baix risc que el professorat pot demanar a l'alumnat per tal d'ajudar-lo a construir habilitats bàsiques amb àlbums il-lustrats i exercicis per fer al seu voltant per treballar sobre habilitats de pensament crític. Els àlbums il-lustrats es perceben sovint com a simples i adreçats a infants, però molts àlbums tenen diferents capes que els converteixen en eines magnífiques per a qualsevol curs de literatura.

Paraules clau: alumnat de primer curs de carrera, àlbums il·lustrats, motivació de l'alumnat, curs de literatura, habilitats/estratègies transferibles

\section{Introduction}

In teaching first year English, I am continually moving towards giving students more opportunities to engage through in-class discussion, group work, and workshops. Although my first-year English courses' main objectives are to teach either critical analysis or writing research papers, I recognize that most students are in their first year of university and still learning how to be successful in a university setting. Thus, I also see my course as an opportunity to help students learn strategies and introduce them to resources that allow them to better navigate the stresses of university. My focus is tied to my concerns about student mental health and wellbeing. Children's literature helps to meet my course objectives, as well as being an important part of my teaching pedagogy focusing on strategy development and student well-being. In this article, I argue that picturebooks are a useful teaching tool in a first-year literature course, regardless of its focus, and use my own experiences and approaches to teaching picturebooks, 
along with examples of student work, to show that picturebooks can lead to diverse and critical discussions that help students develop strategies and reach course objectives.

I see many of my approaches to teaching first year students reflected in Bill Johnston's (2010)

My focus is tied to my concerns about student mental health and wellbeing. Children's literature helps to meet my course objectives, as well as being an important part of my teaching pedagogy focusing on strategy development and student well-being discussion of the First Year Experience (FYE), which he describes as the transitionary phase into university that is a varied experience influenced by the increasing diversity of student backgrounds. Johnston's goal is to suggest ways to create a better FYE for as many students as possible. Although he calls for a university-wide approach that sees coordinated strategies implemented at all levels and across campus, Johnston acknowledges that depending on institutional culture and attitudes towards teaching, instructors may find themselves trying to implement some of his strategies in an individual course.

Johnston (2010) describes a good FYE as allowing students to not only learn content, but also gain skills and strategies that they can take forward. The class should be structured around activities, support, feedback, and assessment that will build selected skills. Johnston believes that first-year learning is best cultivated in an environment that is open and engaging, while shifting the focus to students experiencing learning instead of simply listening to lectures. In essence, a good first year class will make the learning process "collaborative, cumulative and constructive," and have "engaged and empowered" learners who are encouraged to think in "deep, reflective, analytical, and creative" ways (p. 41). Similarly, I aim to have my first-year classes focused on engaging in strategies, supporting student needs, and giving choices that reflect both their interests and their learning needs.

I have taught picturebooks in two different first year English literature courses at the University of Alberta, ENGL 102: Introduction to Critical Analysis and ENGL 103: Case Studies in Research. ENGL 102 is focused on teaching students to critically analyse and read a variety of texts and requires the instructor to cover different genres, time periods, topics, and approaches in the course texts. The requirements of this course mean that picturebooks, and any other children's literature, are just one part of the course. The focus of ENGL 103 is on teaching students to write a research project and allows the instructor to choose a case study (in my case, children's literature) to teach the process of academic research, as well as critical analysis. I generally link my case study of children's literature to a theme, such as "time and space" or "representations 
of childhood," and select picturebooks based on that theme and the foundational skills of the course. I scaffold the assignments in both these courses, beginning with low-stakes assignments to practice the foundations, such as understanding, using, and citing a secondary source, or doing a short close-reading, and build to the longer essays that finish these courses. I cover picturebooks near the beginning of both courses, so my teaching of them is connected to building foundational skills and strategies through in-class engagement and feedback. I rarely lecture in my courses, instead focusing on group discussion and work, class discussion, working through examples as a class, allowing students to practice strategies, and assignment workshops for peer and instructor feedback.

Although I approach my teaching of picturebooks similarly in both ENGL 102 and ENGL 103, there are some differences. In ENGL 102, picturebooks are used to introduce close reading of literature in general, while in ENGL 103, picturebooks serve as an introduction to discussions around children's literature. In this article, I begin with an outline of the advantages of using picturebooks as a teaching tool, followed by my method of using a picturebook in a general English literature course like ENGL 102, and then expand on additions for courses with a stronger children's literature focus, like ENGL 103.

\section{Strengths of Picturebooks as a Teaching Tool}

I cover picturebooks at the beginning of both courses because they are an excellent way to introduce close reading and analysis, while also helping with early student engagement and confidence. From this standpoint, picturebooks help meet my teaching objectives in first year English literature courses in three ways: First, although it may seem very basic, picturebooks are generally not as intimidating to first year students as other forms of literature. Students feel they can more easily understand and grasp a picturebook, and thus are more willing to participate in discussion and activities. Second, students have some familiarity with picturebooks. They likely have a favourite book from their childhood and have memories of reading it and why they liked it. For engagement, there is nothing better than personal connection and experience. Third, while students know and have read picturebooks, it is unlikely that they have interrogated why and how they

I cover picturebooks at the beginning of both courses because they are an excellent way to introduce close reading and analysis, while also helping with early student engagement and confidence. understand a picturebook in a particular way, and if there are other ways to understand it. Students often come to class thinking of picturebooks as simple, but they can quickly be shown the multiple layers of meaning and complexity in a picturebook 
that comes from closer observation. Although students have read and analyzed novels, poetry, and plays in high school, they likely have not approached a picturebook since primary school and have little knowledge of how to read and analyze pictures. This lack of background generally makes students more open to learning new approaches and more inclined to use secondary readings for assistance.

There are many studies focused on using picturebooks as a teaching tool for children and youth, but only a few that take this subject into the university classroom or focus on adult learners. However, the studies that do focus on picturebooks in the university classroom find similar advantages and strengths to what I just listed. Daly and Blakeney-Williams (2015) see the advantages of picturebooks as a teaching tool in their accessibility (both in availability and familiarity), their ability to connect adults to their child selves and in turn the book, their ability to break negative perceptions and build confidence, and their use to grab students' interest to help fill knowledge gaps. The university students that Meyerson (2006) surveyed rated reading picturebooks in class the most positively of all classroom activities, which they noted helped them understand concepts and theories, while also being a nice change of pace. For Meyerson (2006), picturebooks can be a powerful learning tool as long as they are not overused. Student biases of the simplicity of picturebooks are addressed by explaining why they are being used, and care is given so students do not form simplistic understandings of theories and concepts being taught using picturebooks. Maizonniaux (2017) surveyed students before and after picturebooks were used in their university-level language and cultural studies course. The students moved from seeing picturebooks as simple, for children, and with images that just illustrated the text, to seeing picturebooks as sophisticated, rich, and complex. They also showed engagement in the texts as their thinking shifted to address questions debated in picturebook research. Maizonniaux (2017) emphasizes the importance of balancing accessibility and stimulation (or simplicity and complexity) when choosing picturebooks to teach, as this balance is important to student engagement and productive learning.

For new language learners, the language level of picturebooks is often appropriate to their own, while the books also provide enough depth and complexity to keep adult learners engaged.
While Meyerson (2006) suggests that university instructors from many disciplines can use picturebooks effectively in their classrooms, and Daly and Blakeney-Williams (2015) include instructors from a variety of curriculum areas in their study, both these studies are focused on teacher education programs, and Maizonniaux's (2017) study is of French language learners. The benefits or reasons to use

picturebooks in courses for pre-service teachers and new language learners is more evident than 
in a general literature course. Pre-service teachers will soon be teaching children and looking to pedagogical approaches to use in their future classrooms, where picturebooks can naturally take an important role. For new language learners, the language level of picturebooks is often appropriate to their own, while the books also provide enough depth and complexity to keep adult learners engaged. In this article, I add to this field of knowledge by focusing on another area of study, literature, where picturebooks are a beneficial teaching and learning tool at the university level and continue to be overlooked and misrepresented.

\section{The First Impression Approach}

I always start discussing a picturebook in class by using a "first impression" approach, asking students to look at the outside of the book: what does the book suggest to them by its shape, size, colour, title, font, and cover illustrations? Students often discuss what age group the book is geared toward, the mood or atmosphere of the cover illustration, and suggest hints given about the story inside and its focus. Figure 1 shows the results of one class's first impression discussion of Shaun Tan's The Arrival. This group of students focused on the book's cover. They began with broad ideas about the style and setting but soon focused in on certain objects, characters, colour, lighting, cover design, and even the title itself, and connected them together to begin forming a concept of the whole book. Most notably, the students have already caught onto the importance of interactions and relationships over place in this story, which came from taking their readings of the characters (the man and the creature) and objects (the man's clothes and suitcase) on the cover "photo" that does not have any suggestion of background or place.

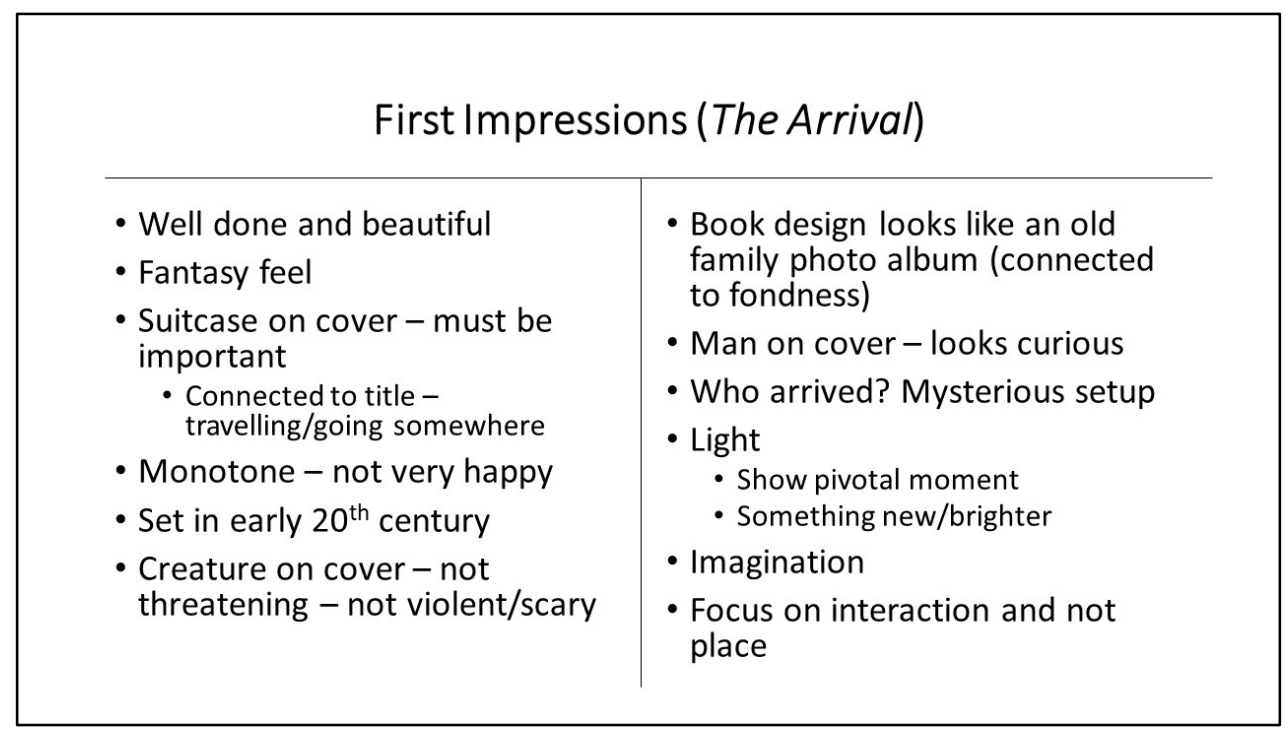

Figure 1. A recreation of the board work resulting from a first impressions discussion of Shaun Tan's The Arrival with an ENGL 102 class.

Maria Nikolajeva (2006) discusses a similar starting approach, saying that she always starts 
the exploration with the picturebook as an object, an artefact. The students are rarely aware of the fact that not only the pictures accompanying the words, but the cover, the back cover, the title page, and the endpapers may contain significant information, as can the size and format of the book, page layout, and other purely format qualities (p. 109).

For example, when I teach Nicola Campbell's Shin-chi's Canoe (2008), which follows the experiences of an Indigenous brother and sister as they attend residential school, I ask students to also read the cover flaps, which include a description of Campbell (who is Interior Salish and Métis) interviewing elders and family who survived residential school to help write the book. I also point them to Campbell's (2008) introduction, where she briefly describes the history and impacts of residential schools, but also states that "steadfast resistance, determination, courage, healing, strength of spirit and an overwhelming love for our children and culture are the tremendous forces that have empowered indigenous peoples around the world to overcome the profound impact that this part of history has had on them" (p. 1). When Shin-chi's Canoe, I give students a brief overview of the activism, experiences, and mistreatment of Indigenous peoples in Canada, as students have different levels of knowledge, and emphasize that these issues are still unresolved and are relevant to current experiences of Indigenous peoples in Canada. I ask students to consider what intended audience these cover flaps and introduction indicate, as well as what message the book wants to send. The discussion often covers the introduction as written for white adults in Canada who are reading the book with children and need help answering children's questions. Students may also note that while the book could be for any reader, it does have elements that are present to educate and inform the white reader. I also point to the section of the introduction I previously quoted and guide the conversation towards discussing the children in the story as resilient survivors, who with the help of their family work against the institutional and governmental systems attempting to strip them of their culture and identity.

\section{Critical Reading of Illustrations}

My next step in teaching students a picturebook is to focus on the pictures and how they tell the story. This step is more straight-forward with a wordless picturebook, as words always influence readers, but asking students to focus on the pictures first, even in a picturebook with words, is a good way of introducing how to do close reading that gives detailed examples and explanations. When I take this picture-focused approach with a picturebook that has words, I also include a discussion on how words and pictures influence each other. 
In my ENGL 103 class, I have students read Perry Nodelman's (1988) chapter on the relationship of pictures and words to help with this discussion, but it is not difficult to summarize the main points for students. Nodelman (1988) argues that words influence how we read pictures and vice versa and take on a different meaning together than they would separately, as they "limit" each other (p. 221). Words and pictures have different strengths, with words giving context and focus for which the pictures can give specifics and extra details not in the words, especially in their style and characterization. While words describe things we have experienced, pictures can show us things we do not know or have the words to understand.

Their focus is on the importance of context, which the words provide, that is lost when just reading the pictures and takes away a lot of the weight of the story and its residential school setting. The students also note that the message of hope and resilience in the story, related to family bonds, is also lost without the words for guidance. Nodelman (1988) also includes a description of an experiment he did that asked participants to describe the story of a picturebook from viewing only the pictures. Although the experiment cannot be fully replicated, as students generally have already read the book when they come to class, asking them to think about what story and meaning they get from the pictures alone is a good method to demonstrate the relationship between words and pictures in picturebooks. Figure 2 and Figure 3 show the results of two ENGL 103 classes reading Shin-chi's Canoe without the words. Their focus is on the importance of context, which the words provide, that is lost when just reading the pictures and takes away a lot of the weight of the story and its residential school setting. The students also note that the message of hope and resilience in the story, related to family bonds, is also lost without the words for guidance.

By asking students to focus on the pictures for their analysis, they cannot just quote the words on the page as their example but must explain what they see and how particular parts of the image affects their understanding. To help, I cover some basic concepts from Molly Bang's (2000) Picture This: How Pictures Work, giving a summary of Bang's explanations of how shape, size, and placement can affect the reading of an illustration and drawing versions of the illustrations that Bang uses as examples in her book. Figure 4 is an example of what students have access to in the online classroom after class for reference. This slide is an example of the minimum information students need, but I have also introduced quotes from Bang's book to expand on these concepts. 


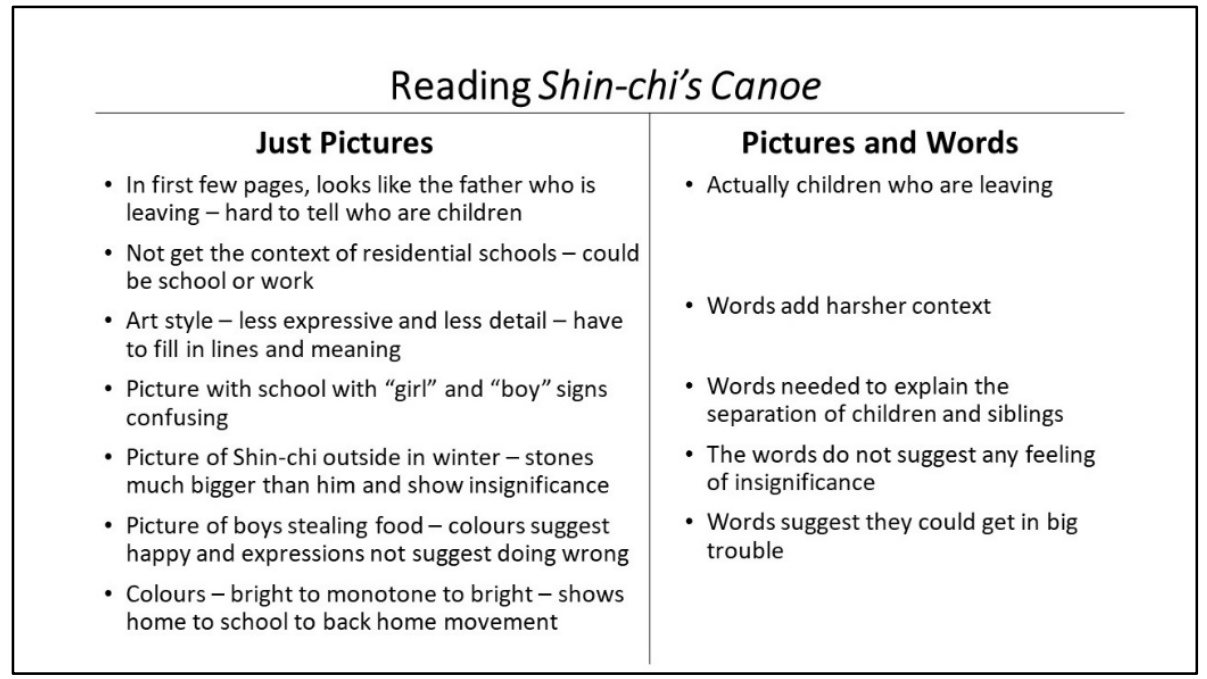

Figure 2. A recreation of board work that resulted from a discussion of reading words and pictures in Nicola Campbell's Shin-chi's Canoe with an ENGL 103 class

\begin{tabular}{|c|c|}
\hline \multicolumn{2}{|c|}{ Reading Shin-chi's Canoe } \\
\hline $\begin{array}{l}\text { Just Pictures } \\
\text { - Miss the darker story/tragedy because of the } \\
\text { soft art style } \\
\text { - Never see faces - about context around them } \\
\text { - Some sense of darker tone } \\
\text { - Cutting braids } \\
\text { - Isolation - monotone colours } \\
\text { - Get sadness - working, saying goodbye } \\
\text { - Significance of the canoe is unclear } \\
\text { - Jumping around in time - confusing } \\
\text { - Not see difference in race of characters } \\
\text { - No school work shown - just manual work } \\
\text { - Not many details }\end{array}$ & $\begin{array}{l}\quad \text { Pictures and Words } \\
\text { - Words explain symbols in pictures } \\
\text { - Words explain the plot where the pictures } \\
\text { lack detail } \\
\text { - Words give context but the pictures show } \\
\text { the most relevant/important parts of } \\
\text { characters } \\
\text { - Words convey hope through family bonds } \\
\text { - Pictures show less hardship than the words } \\
\text { suggest } \\
\text { - Introduce children to residential schools - } \\
\text { resonate not complicate } \\
\text { - Words give personal connections between } \\
\text { characters }\end{array}$ \\
\hline
\end{tabular}

Figure 3. A recreation of board work that resulted from a discussion of reading words and pictures in Nicola Campbell's Shin-chi's Canoe with an ENGL 103 class (different class from figure 2)

For example, the third image in the third row and the first image in the fourth row show how "We feel more scared looking at pointed shapes; we feel more secure or comforted looking at rounded shapes or curves" (Bang, 2000, p. 70). It is helpful to ask students what they associate with rounded versus pointed shapes, starting with the landscape-like images on the board, to note how rolling hills are easy to traverse and associated with sunny days, while mountains are difficult to climb and dangerous. Students may also connect roundness to a stuffed animal or pointedness to a knife. I introduce each piece of information individually and draw the images as I go. It is important to give students time to take each image in and ask questions, as generally this lesson is their first in reading pictures, and to leave the images on the board for students to reference in their practice readings. 


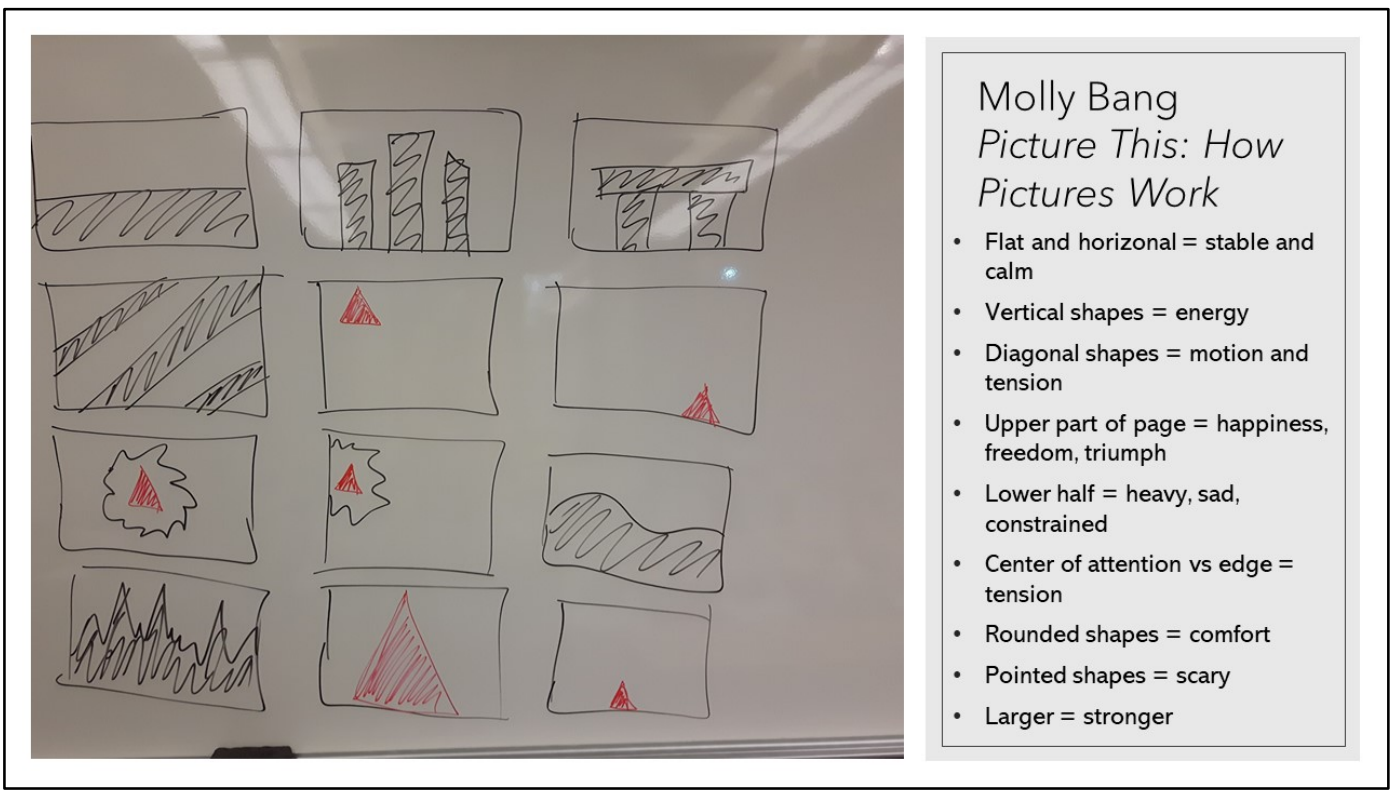

Figure 4. An example of the information you can provide students to begin reading pictures ${ }^{1}$

Although Bang discusses how the shape and placement of objects affect a picture, students can find that tight focus limiting and difficult for their first

It is helpful to ask students what they associate with rounded versus pointed shapes, starting with the landscape-like images on the board, to note how rolling hills are easy to traverse and associated with sunny days, while mountains are difficult to climb and dangerous practice reading. To give students more options, I suggest other visual aspects of the book to consider: font type, size, and colour; where the words and illustrations are placed on the page; the use of white space and borders to separate images and/or words; colours in illustrations; and the design of characters, their facial expressions, and postures. As I introduce each group of concepts, I have students find examples in the picturebook and discuss as a class how these aspects affect how we read the illustration, full page, and book as a whole.

When I use Shin-chi's Canoe, for examples of colour, students often point to the more varied and vibrant colours of the beginning and end of the book, when Shi-shi-etko and Shin-chi are at home with their family, which diminish when the children are at residential school. When I ask why they think the colours change, students generally point to the oppressive nature of the school and the children's hardship, often using the example of the double spread of children in the dining hall having meagre portions of bland food while the teachers in the next room eat full meals of meat and vegetables (Campbell, 2008, pp. 21-2). The only colours used in the image

\footnotetext{
${ }^{1}$ This example is best used when there is limited time (more information can be given if there is more time)
} 
are greys and a muddy yellow, with the exception of a splash of colour on the teachers' food. Also, although the teachers' dining room is lit, the students' dining hall is in shadow, lit only by the light of the other room. Students often note the lack of colour highlights the lack of nutrition and the blandness in the children's food, and the shadow represents their sadness at being split from their siblings and not allowed to speak to each other. On the previous page, this separation is made clear with the pictures of Shi-shi-etko and Shin-chi doing their gendered tasks while being separated by text and white space (Campbell, 2008, p. 20). This page works as a good example of how borders, white space, and the layout of a page are important to consider in picturebook analysis.

\section{Engaging Students Through Focused Close Reading}

Having discussed as a full class our initial impressions of the picturebook and different aspects to consider when reading picturebooks, the next step is for students to use their new reading and analysis strategies, either individually or in groups. If students are working individually, they pick their own page to analyze. This option is best when students do this practice outside of the classroom; for example, if class time is running short and students are given the analysis for homework, with the results discussed in small groups or as a full class in the next session. Once, when I cancelled an in-person class because of extreme weather at the beginning of the picturebook section of an ENGL 103 course, I moved the class online by posting the slideshow with the Molly Bang images and explanations, plus the list of other aspects to consider, and had each student post an analysis of a page of Shin-Chi's Canoe of their choice. Between 40 students, almost every page was covered, and most students gave very detailed and varied analysis. I used their work to shape the questions for our class discussion the next day, to expand on the many symbols, themes, and concepts they had already identified.

If this first picturebook analysis is during class time, the most productive approach is to put students in small groups and assign each group a page in the picturebook. While in individual work students focus on a page that they find interesting or appealing, groups can take on the challenge of an assigned page so that a variety of pages are covered. Assigning pages also removes time wasted on groups discussing which page to analyze. With Tan's The Arrival, each group has two specific illustrations or pages to compare, with two groups comparing the same pages to get different perspectives and ideas. In having students compare two pages, I ask them to focus on each individually, then together, and then in relation to the whole book.

The goal is for students to make a focused analysis and comparison that they can use as an example for a larger concept, theme, or analysis of the book. For example, one pair of pages 
assigned in The Arrival are the first in chapter I and chapter IV. Each has a grid of nine images of objects from the family's home before and after they immigrate, respectively. Whereas individually the objects give insights into the family and their lives in both locations, a comparison shows how their lives have evolved but also how their family connection has stayed the same, with household objects like the kettle and clock looking drastically different, but also the continued inclusion of the family portrait, the daughter's drawings, and the father's origami animals. From there, students can take symbols, like the origami animals that show up throughout the book and compare their use in other sections of the book to help them further form the overall meaning.

With a list of elements to consider when analysing picturebooks, students usually do a good job of describing details and explaining how they see those details affecting the meaning of the book. As with any text where students are asked to give detailed examples to support an analysis, students can tend towards plot points and generalities. Surprisingly, tending towards generalities happens more with Tan's wordless picturebook, likely because students feel that without any words, the plot is all they need to discover. The best solution is to always ask students to explain how they know the plot: Why do you think that is what happened? What in the picture made you think that? How did the characters on the page and their expressions, gestures, clothing, colouring, etc. lead you to that understanding? It is good practice for

I find that picturebooks are a great introduction to focused reading because giving students one page or image does not feel overwhelming, but still gives them a lot to work with. Also, when focusing on a single illustration, it is much harder to give generalities and students cannot just point to a quote the instructor to move between the groups to ask these types of questions and point to further pieces in the images that students could consider. Even with that caveat, I find that picturebooks are a great introduction to focused reading because giving students one page or image does not feel overwhelming, but still gives them a lot to work with. Also, when focusing on a single illustration, it is much harder to give generalities and students cannot just point to a quote. They quickly see the need to describe and explore the details they see in the image. Even the difficulties that arise from wordless picturebooks can be helpful so students are aware of the kind of questions they should be asking in their analysis.

In ENGL 103, I cover three picturebooks over two weeks, having students read two secondary sources throughout: the Perry Nodelman (1988) chapter and Maria Nikolajeva and Carole Scott's (2006) chapter on time and movement. Both are straight-forward readings that discuss various ways to approach and read picturebooks. Nodelman's chapter is particularly useful to help 
students think about how pictures and words work together in a picturebook to tell a unique story, instead of the illustrations being just visual additions that have little consequence. Nikolajeva and Scott cover in detail how pictures can suggest or show movement and the passage of time, which Nodelman also touches on in how words and pictures cannot be split into representing time and space.

In my last few ENGL 103 courses, I paired Nikolajeva and Scott (2006) with Jon Scieszka and Lane Smith's (1992) The Stinky Cheese Man and other Fairly Stupid Tales, because it is filled with examples of movement and time in pictures. Nikolajeva and Scott cover many different techniques of showing movement, so I begin the class by asking students which techniques they see being utilized in the Scieszka and Smith's book. One technique students point to is the use of a pageturner in "The Tortoise and the Hair." In this story, Tortoise is racing Rabbit's growing hair, which can be seen sprouting from Rabbit's head in the first illustration and leading to the next double-page spread (Scieszka \& Smith, 1992, pp. 31-2). The hair winds around the double spread, spelling "not" in front of "the end" and continuing again past another page flip to the "once" that begins the next story called "The Stinky Cheese Man" (Scieszka \& Smith, 1992, pp. 32-34). When students are asked what the pageturner is used for in this instance, they often point to the hair drawing the reader to turn the page, but then subverting expectations in twisting around and leading to an unrelated story. As the story ends with Tortoise and Rabbit's race still ongoing, the discussion can move towards how Scieszka and Smith play with time and our expectation for stories to have endings.

This story also has a good example of simultaneous succession in the multiple images of Tortoise climbing a rock with his watch's time changing (Scieszka \& Smith, 1992, p. 33). Students find this example quickly and with some guidance can think through how the use of this technique is also playing with time. Although Nikolajeva and Scott (2006) say that "the change occurring in each subsequent image is supposed to indicate the flow of time between it and the preceding one" (p. 140), the images of Tortoise have only slight changes besides his watch and move in a circular shape, which challenges our understanding of the flow of time. Besides learning about ways that pictures show movement, Nikolajeva and Scott give students terms to use in their discussion of illustrations that add to their confidence in their analyses.

The Stinky Cheese Man and Other Fairly Stupid Tales is a good picturebook to use in a first-year literature course because it is accessible and works well with my teaching approach. This postmodern picturebook uses every inch of its printed surface, from endpapers to the ISBN number, to help tell its story and play with expectations, so discussing first impressions and the 
elements of the book encourage student thinking. This book can be paired well with Bang (2000), Nodelman (1988), or Nikolajeva and Scott (2006) as it has examples of many of the methods and techniques for reading picturebooks that are noted in the readings and can stand alone or introduce these aspects of reading for a course. It is an especially good pairing for Nodelman, because The Stinky Cheese Man takes his discussion about what words and pictures do best and how both come together to tell a particular story a step further by making the words part of the illustrations and action.

\section{Encouraging Critical Thinking}

One exercise, which generally takes up a full 50-minute session, is a student-led discussion about what we expect from picturebooks and fairy tales, and how Scieszka and Smith's book breaks those expectations. This discussion is very The students discussed the critique on fairy tales and their unrealistic portrayal of life experiences, the parodying of fairy tales being both for humour and to challenge binaries, as well as the need for readers to have a knowledge of fairy tales to understand the book fully and how that means people at different ages will experience the book differently useful in my ENGL 103 course as it challenges students to think about their own personal definitions and biases towards picturebooks and children's literature in general. Figure 5 shows the first half of this exercise that focuses on fairy tales. Students expected fairy tales to teach a lesson, be exciting and adventurous, and have a happy ending, but found Scieszka and Smith's book to be silly, pointless, and anti-climatic without satisfying endings. Students then responded to a question about why they think the book works against these expectations and the subsequent results. The students discussed the critique on fairy tales and their unrealistic portrayal of life experiences, the parodying of fairy tales being both for humour and to challenge binaries, as well as the need for readers to have a knowledge of fairy tales to understand the book fully and how that means people at different ages will experience the book differently.

Figure 6 shows the second half of the exercise with the same class. While their expectations for picturebooks were that they are visually appealing and contained complete stories, they found that The Stinky Cheese Man plays with visuals in ways that are not conventionally appealing and with the idea of the book as a constructed text, having characters aware they are in a book and using pieces of the book and its creation to tell or change their stories. When I asked why these creative choices were made, students pointed to humour, but also to the book being a helpful way to teach children about book construction and a variety of storytelling methods, including 
self-aware characters. This discussion of The Stinky Cheese Man is an excellent way to introduce students to postmodern picturebooks and concepts such as metafiction. As figures 5 and 6 show, students are already making the connections to The Stinky Cheese Man as metafiction in their references to the making and construction of the book as part of the story. For a short assignment that has students using a secondary source to help support their reading of a text, I give the option of pairing The Stinky Cheese Man with Deborah Stevenson's (1994) article on the postmodern nature of the picturebook, which gives interested students more background on the elements of postmodern picturebooks.

\section{Fairy Tales}

\section{Why?}

1) Criticize fairy tales - what they've become - originals are scary/gruesome

- More realistic (not always happy ending) - nothing happens

- Humour

2) Makes point to jump around - play with plot/events

- Once upon a time - hopes/dreams/imagination

- Comic relief

- Realism - not make sense to have happy ending

- Assumes have background knowledge of fairy tales - for older audience/expand horizons of reader/make stories more intering

- Get out of mindset of expencting happy endings - darker endings

3) Have fun/enjoy

- Catches you off-gaourd/engaged

- Good vs evil not here - rejects boundaries

- Flipping sotires actually makes adventurous

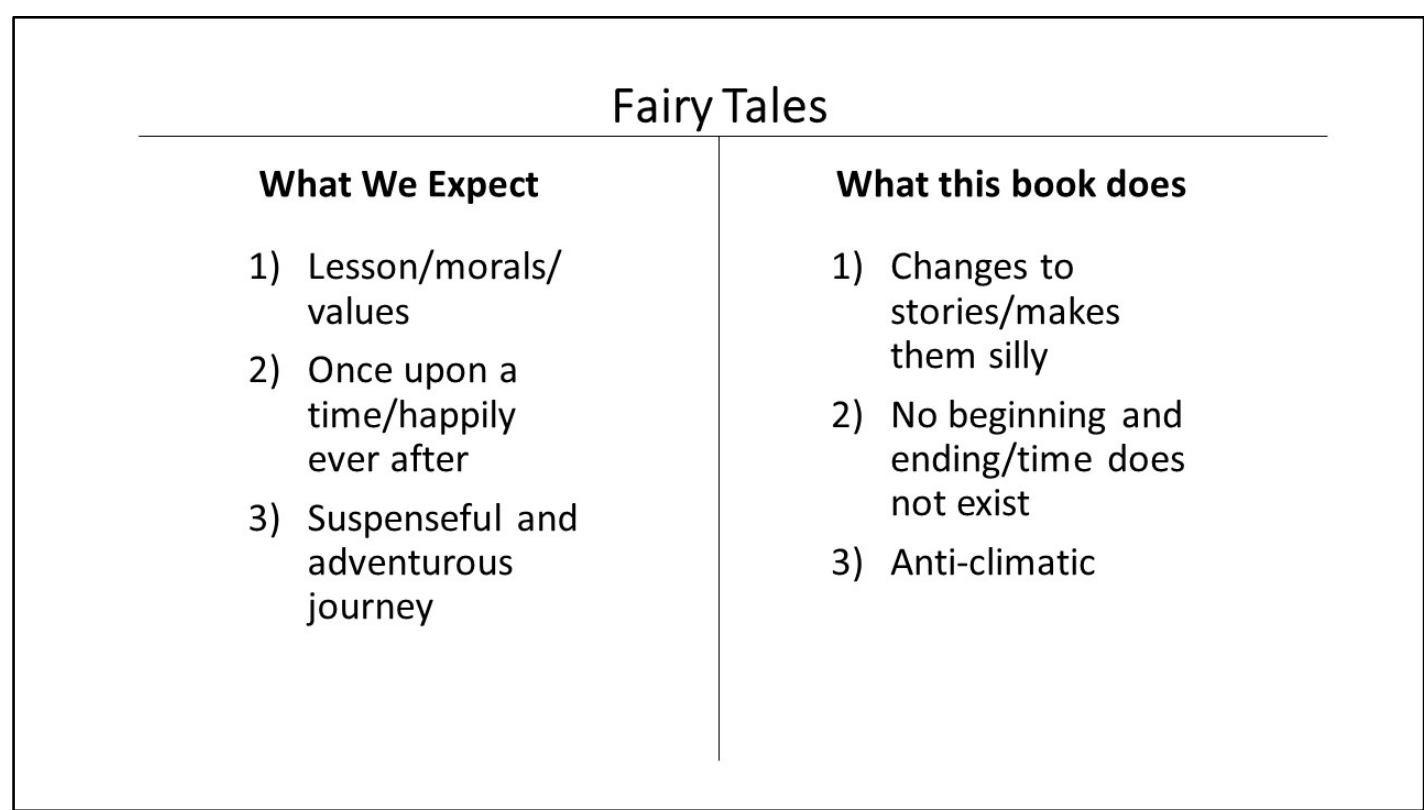

Figure 5. A recreation of the board work that resulted from a discussion about what the students of an ENGL 103 class expected from fairy tales and what they actually observed in Jon Scieszka and Lane Smith's The Stinky Cheese Man and Other Fairly Stupid Tales 


\section{Picturebooks}

\section{Why?}

1) Play up comedy

- Introduces fourth-wall breaking and meta to children

- Happening as you read

- Changing as you go

- Constructed as you go

- Breaking away from stereotypical - breath of fresh air

- Reader plays a role

2) Art style breaks out of page - part of characters

- Font is art itself

\section{Picturebooks}

What We Expect

1) Contained story

2) Aesthetically pleasing

3) Complete/whole

\section{What this book does}

1) Meta-ness/fourth wall breaking

2) Photos/collages/ugly

3) Construction is ongoing

- Not put together - look like from magazine

- Need to work to find meaning in the pictures (ex. Giant)

- Order changes - narrator messes (ex. Little Red)

- Blank pages - fast paced/changes - Changes sequence/ disorganized

- Characters acknowledge table of contents

- Title pages says "Title Page"

- Hen's story before book beings

- Upside down - interaction

- Every part of the book part of story (ISBN)

- Book dangers (stamp) - not what expect

- No one cares about the dedication - which is addressed to you

Figure 6. A recreation of the board work that resulted from a discussion about what the students of an ENGL 103 class expected from picturebooks and what they actually observed in Jon Scieszka and Lane Smith's The Stinky Cheese Man and Other Fairly Stupid Tales 
In the following class, we do a short activity suggested in Fuss and Gleason's (2015) excellent book The Pocket Instructor: Literature. I use a version of Johanna Winant's "The New Title" exercise that asks students to rename the book they have been studying. As Winant (2015) suggests, this exercise is best used when students are familiar with the text (p. 37), because students are asked to create a new title based on their discussion and experience with the text so far. It can be a useful way to begin the class as it brings them back to the previous discussion and the ideas that stuck with them, so that after the exercise the discussion can continue with the new titles as a starting point. Alternatively, this exercise can be a fun way to finish up with a text to summarize what the students thought was most relevant in the class discussions. For example, Figure 7 shows the results of asking students to work in groups of three to create a new title for The Stinky Cheese Man and the reasons behind their choices. The titles show that the students considered various parts of the book, such as the complexity of Jack being character, narrator, and creator in the book, the Little Red Hen being a surprise and unwanted character but an essential part of the book, the book's play with story shape and endings, the dynamic of the child and adult reading the book together, and the general silliness and parody the students saw in the book. The students put a lot of thought into the elements they saw as important and how to best represent them.

\begin{tabular}{|c|c|c|c|}
\hline \multicolumn{4}{|c|}{ New Titles for The Stinky Cheese Man } \\
\hline \multicolumn{2}{|c|}{ Title } & \multicolumn{2}{|c|}{ Why? } \\
\hline 1) & $\begin{array}{l}\text { Jack and the Noisy Hen's Unconventional Fairy } \\
\text { Tales }\end{array}$ & 1) & $\begin{array}{l}\text { Tie everything together; Jack and Hen constant } \\
\text { characters; conventional fairy tales with unconventiona } \\
\text { endings }\end{array}$ \\
\hline 2) & Jack's First Picturebook & \multirow[t]{2}{*}{ 2) } & \multirow{2}{*}{$\begin{array}{l}\text { He's building the book throughout; not best attempt; } \\
\text { breaks } 4^{\text {th }} \text { wall }\end{array}$} \\
\hline 3) & Jack's Book of Many Tales ft. An Ugly Duck & & \\
\hline 4) & Chicken Noodle Soup \& Tales & 3) & Ugly duck captures silliness of book \\
\hline 5) & Jack and the Interrupting Hen's Journey Among & 4) & Adult reads to child - comfort/fun \\
\hline 6) & $\begin{array}{l}\text { the Broken Fairy Tales } \\
\text { The Parmesan Parables of the Stinky Cheese Man }\end{array}$ & 5) & $\begin{array}{l}\text { Jack narrator but not in original title; "broken" = breaks } \\
\text { boundaries }\end{array}$ \\
\hline 7) & The Hack's Unexpected Tales & 6) & $\begin{array}{l}\text { Want alliteration-memorable and catch attention; } \\
\text { Stinky Cheese Man significant tale }\end{array}$ \\
\hline 8) & Happlly Ever After & \multirow{2}{*}{$\begin{array}{l}\text { 7) } \\
\text { 8) }\end{array}$} & Play between Jack and Red Hen; unexpected endings \\
\hline 9) & The Hen \& Not the End & & Ironic-unexpected \\
\hline & A Fairly Chaotic Collection of Fairly Stupid Tales & 9) & Get to hear of it; many stories \\
\hline & & 10) & Playful rhythm; no real ending; Hen shows time passing \\
\hline & & 11) & Shows chaos and breaks conventions \\
\hline
\end{tabular}

Figure 7. The responses from an ENGL 103 class's group work that asked them to create a new title for Jon Scieszka and Lane Smith's The Stinky Cheese Man and Other Fairly Stupid Tales and to explain the reason for their choice 
In ENGL 103, the picturebook section of my course ends with students giving short, low-stakes, five-minute group presentations about how they would design their own picturebook while using secondary sources to support their design decisions. For this $5 \%$ assignment, students are graded on their design (2\%), their use of secondary sources (2\%), and their presentation (1\%). The objectives of the assignment are to encourage students to think creatively, practice using and citing secondary sources, and experience presenting to a group. Even though they are only required to describe their design choices and use support from readings covered in class, many groups make full illustrations, do extra research around a particular interest, and come up with very creative and unique designs. Students are given two fairy tales from Angela Carter's Book of Fairy Tales (2005), "The Witchball" and "Now I Should Laugh, If I Were Not Dead," that they can use for the plot of their picturebook, although some groups create their own stories. I have another version of this assignment that has each student work individually and submit a written description of their picturebook design with support from secondary sources. For both versions, I emphasize with students that it is the creativity and effectiveness of their design that they are being graded on, not their artistic skills.

Figures 8 and 9 are a sample from one group's slideshow presentation. For this page of their design, they focus on Nikolajeva and Scott's (2006) discussion on the verso and recto pages, and how contrast between them can help instill meaning. They distinguished the poor boy and rich girl in "The Witchball" by contrasting a black and white drawing, which they associated with the boy's sadness and the disapproval of the girl's family, while the girl is drawn in bright colours to show her happiness and difference from the boy. Figures 10 and 11 are two slides from another group's presentation who used "Now I Should Laugh, If I Were Not Dead." This group focused on using techniques of movement and object placement to help tell their story. They use motion lines and pageturners to create interest and a sense of urgency, they place characters closer to or further from the viewer to suggest different levels of importance, and they use simultaneous succession to show the wife working and time passing. Both these groups used what they learned from reading picturebooks and the secondary sources by Nikolajeva and Scott (2006), Nodelman (1988), and Bang (2000), to effectively present their stories and thus demonstrated their understanding of 'how picturebooks work' by creating their own. I think these results show the potential of picturebooks to help students gain strategies around textual analysis, reading secondary sources, and supporting arguments, but also increase student engagement. Picturebooks can make the practice of close reading and analysis fun and engaging, but also challenge students to step outside their comfort zones to work with a type of text they have likely never analyzed before. 


\section{Design \#1- Adventure Page - Home Page}

- In Nikolajeva and Scott's "How Picture Books Work" they introduce the notion that "the verso establishes a situation, while the recto disrupts it; the verso creates as sense of security, while the recto brings danger and excitement." (151)

- Verso: boy and his home; Recto: the girl in her home

- this is shown in in our story through the contrasting of the lives of the boy and the girl. The girl and the boy have different uses of colour, and setting to depict their differences. The recto represents danger because her family does not approve of the boy and he will not be able to achieve his "adventure" on his own. It is also made to look more visually appealing than the boy's to represent his sadness, and longing and help readers sympathize with him.

Figure 8. An example of an ENGL 103 student group's picturebook presentation. The notes on this slide explains the choices for one of the illustrations they created (see figure 9)

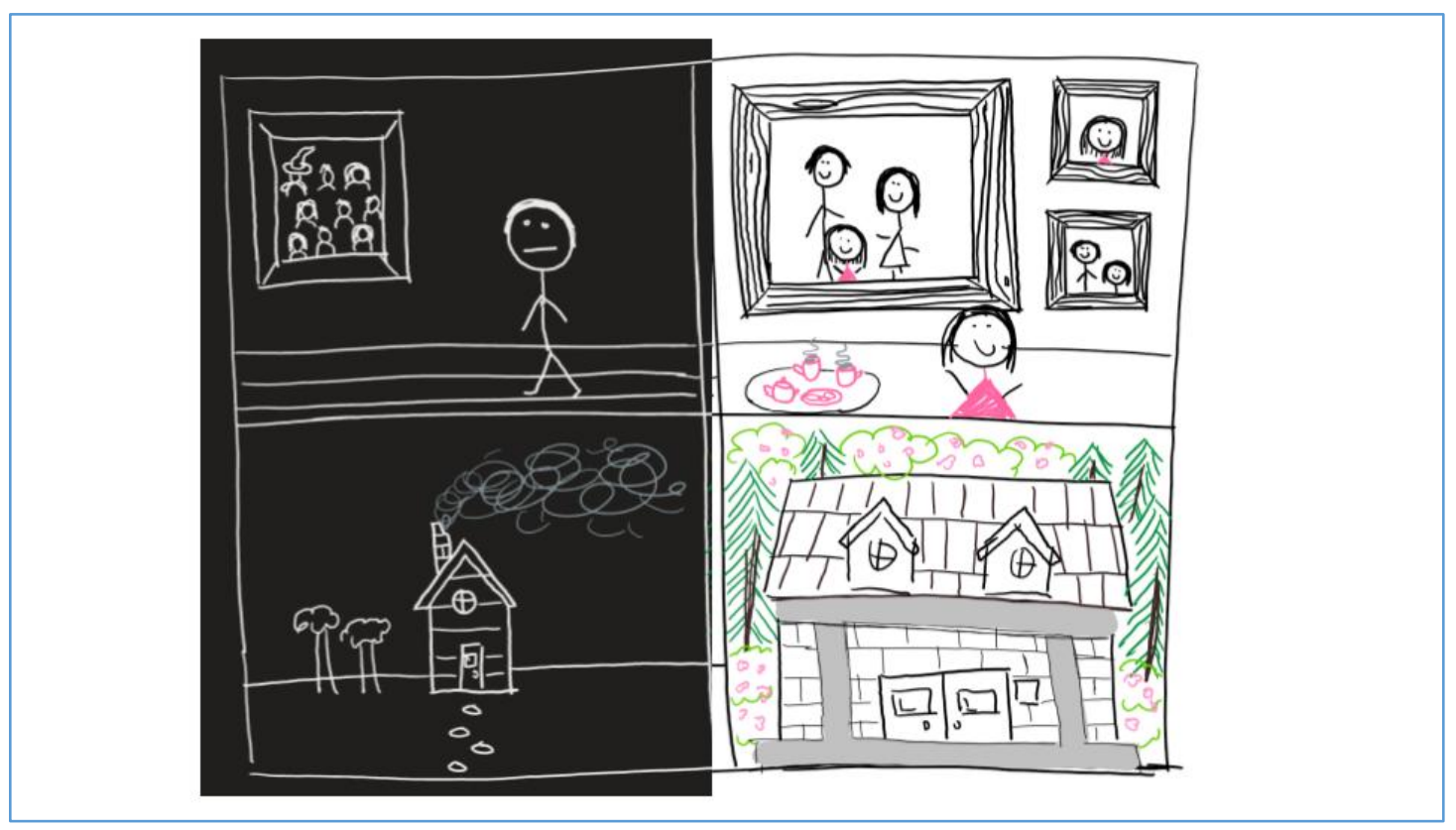

Figure 9. An example of an ENGL 103 student group's picturebook presentation. This is the illustration that the slide in figure 8 references 


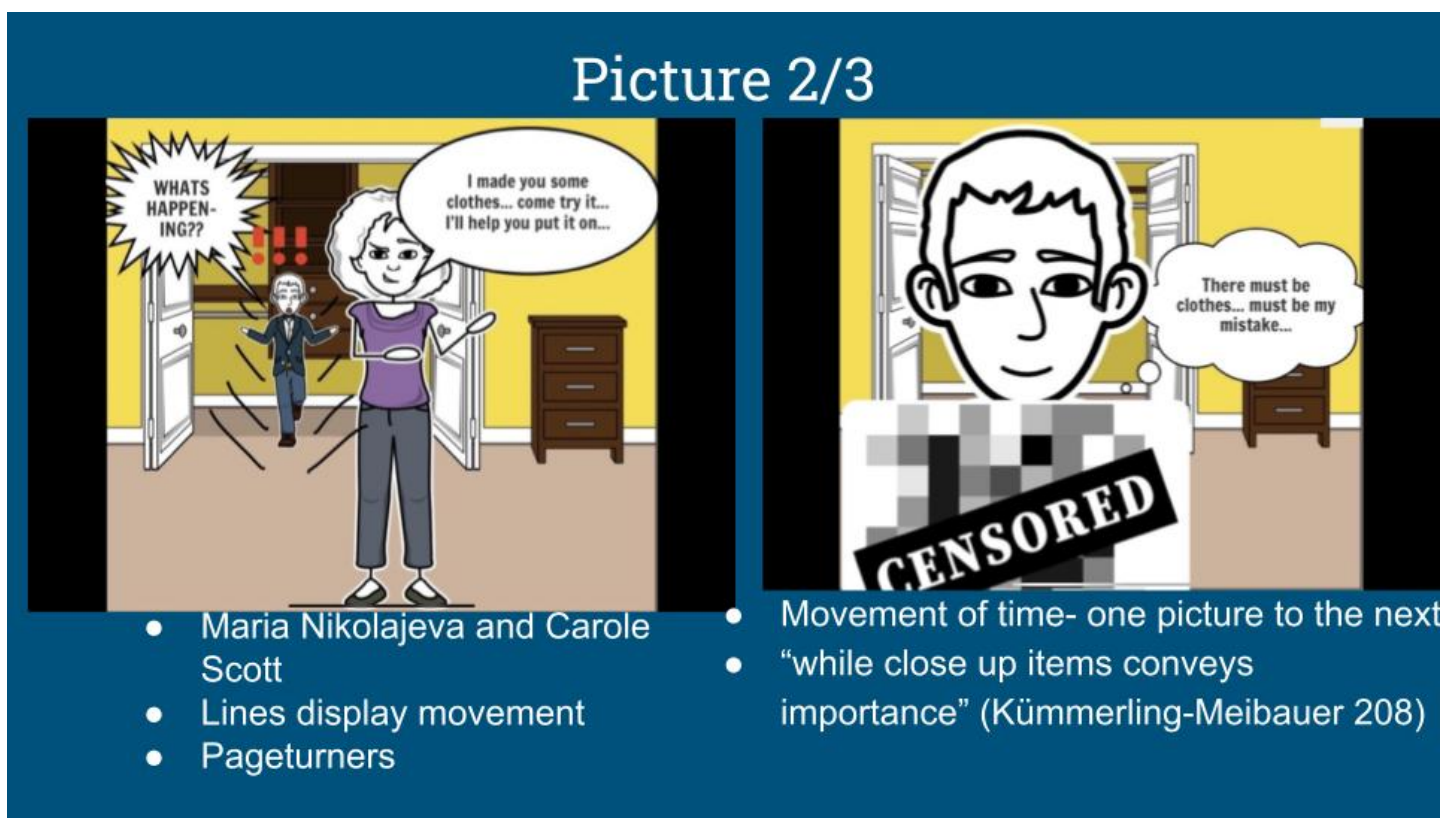

Figure 10. An example of an ENGL 103 student group's picturebook presentation. Figure 11 shows the next slide from the same group

One question to encourage students to build their critical thinking is to consider their understanding of children's literature (or picturebooks) and biases or personal experiences that make their approach to these texts different from other students in the class or even narrow their understanding or critical approach. One exercise for the first day of an ENGL 103 class is to ask students to bring what they consider their 'Top 6 List of Children's Literature.' I give no more explanation. When they come to class, they pair up with a classmate and work together to make their two Top 6 Lists into one Top 6 List. Then they pair up with another group, and then that bigger group pairs with another group, and so on, until the class is in two large groups who have each created a Top 6 List. Both groups write their final list on the board, but the texts in those lists are not the important part of the exercise. As the exercise progresses and students discuss what texts should stay on the list and students defend their choices, they begin to discuss topics that are discussed widely in the children's literature field and to think critically about what they consider children's literature. The group discussions often touch on such topics as the age groups children's literature is aimed towards, age appropriateness of texts, censorship, how to judge the 'quality' of a text, the types of texts considered 'literature,' the topics appropriate for children, and if children's literature should teach a lesson or just entertain. 


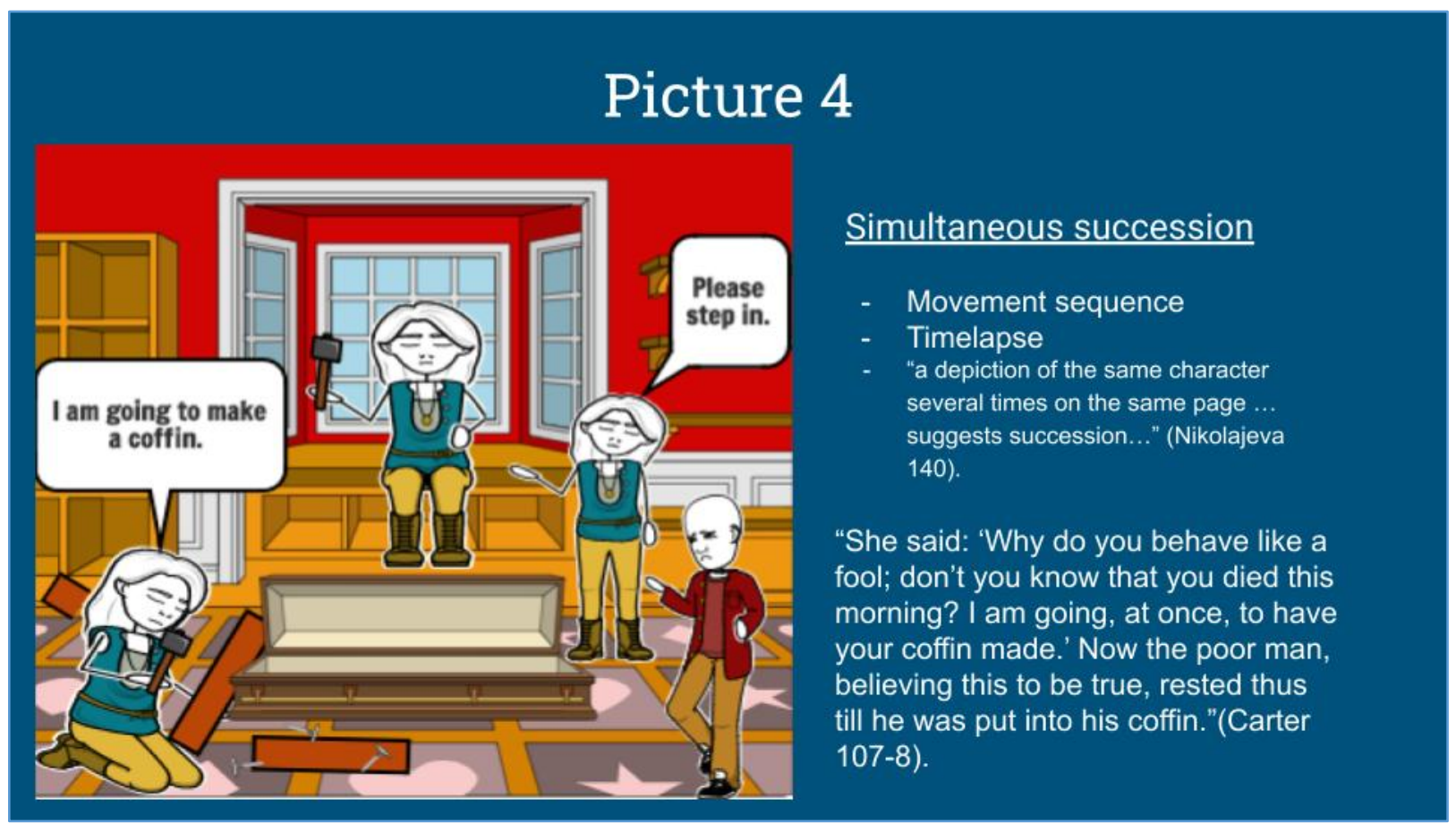

Figure 11. An example of an ENGL 103 student group's picturebook presentation. Figure 10 shows the slide before from the same group

When the final lists are on the board, I ask students who have a text they really wanted included to add that text on the board. Then, I ask students what is missing. Often most texts on the lists have white authors and main characters, are perceived as

Students have important questions to ask of their own and other's readings of the texts covered in the class, which they already began asking when they attempted to understand what children's literature meant to them in the first class classics, and present a Western experience. These are important questions to begin asking at the start of any course, but I make this focus when teaching children's literature because our value judgements and methods of comparing and analyzing children's texts are often based on our own nostalgic memories and particular experiences of childhood. The next class focuses on Marah Gubar's (2011) “On Not Defining Children's Literature," which provides students with discussions in the field around the power and place of adults in children's literature, how the variety and diversity in children's literature is approached, and the challenges around defining the genre. With this critical background, students have important questions to ask of their own and other's readings of the texts covered in the class, which they already began asking when they attempted to understand what children's literature meant to them in the first class. 


\section{Conclusion}

Picturebooks are perceived as being simple and for young children. My goal is to change this perception with students and the aim of this article is to do the same with instructors. Daly and Blakeney-Williams (2015), Meyerson (2006), and Maizonniaux (2017) have noted the effectiveness of picturebooks to be accessible and build student engagement and confidence, while teaching them effectively also breaks misconceptions about the simplicity of picturebooks to encourage deeper and more complex thinking and understanding in students, especially when they are introduced to difficult topics, concepts, or theories. While their studies focus on teacher education and language courses, I want to bring the conversation about the

I have outlined methods to approach teaching picturebooks that cover the outcomes of many university literature courses, especially firstyear mandatory courses, including image and visual literacy, close readings, critical thinking, and the reading and effective use of secondary sources effectiveness and benefits of teaching picturebooks at the university level into the general literature course. I have outlined methods to approach teaching picturebooks that cover the outcomes of many university literature courses, especially first-year mandatory courses, including image and visual literacy, close readings, critical thinking, and the reading and effective use of secondary sources.

Picturebooks are exceptionally varied in their topics, styles, and complexity, and first-year literature instructors can find a picturebook that will suit their class. At the end of each course, I ask students what texts they would want to keep in the course if they were to take it again. Picturebooks are always at the top of the list. Including a picturebook increases student engagement and sense of confidence so they feel more comfortable participating and contributing to class and group discussions, and keeps students open to new ways to read and critically analyze a text. With the proper questions and exploration, picturebooks lead to deep, reflective, analytical, and creative thinking. Picturebooks are fun and engaging for students, but also introduce important reading and writing strategies that they need to be successful in their university and future careers. They are an effective teaching tool that I encourage university instructors to consider adding to their courses. 


\section{References}

Bang, M. (2000). Picture this: How pictures work. Chronicle.

Campbell, N. I. (2008). Shin-chi's Canoe (K. LaFave, Illus.). Groundwood.

Daly, N., \& Blakeney-Williams, M. M. (2015). Picturebooks in teacher education: Eight teacher educators share their practice. Australian Journal of Teacher Education, 40(3), 89101. http://dx.doi.org/10.14221/ajte.2014v40n3.6

Gubar, M. (2011). On not defining children's literature. PMLA, 126(1), 209-16. http://www.jstor.org/stable/41414094

Johnston, B. (2010). First year at university: Teaching students in transition. McGraw-Hill.

Maizonniaux, C. (2017). Australian university students reading francophone picturebooks - An original study. Bookbird: A Journal of International Children's Literature, 55(1), 24-32.

https://doi.org/10.1353/bkb.2017.0003

Meyerson, P. M. (2006). Using children's picturebooks as tools to facilitate undergraduates' learning. College Teaching, 54(3), 259-262. http://dx.doi.org/10.3200/CTCH.54.3.259- 262

Nikolajeva, M. (2006) Word and picture. In C. Butler (Ed.), Teaching children's fiction (pp. 106-51). Palgrave Macmillan.

Nikolajeva, M., \& Scott, C. (2006). Chapter 5: Time and movement. How picturebooks work (pp. 139-72). Routledge.

Nodelman, P. (1988). Chapter seven: The relationships of pictures and words. Words about pictures: The narrative art of children's picture books (pp. 193-221). University of Georgia Press.

Now I should laugh, if I were not dead. (2005). In A. Carter (Ed.), Angela Carter's book of fairy tales (pp. 107-8). Virago.

Scieszka, J., \& Smith, L. (1992). The Stinky Cheese Man and other fairly stupid tales. Penguin.

Stevenson, D. (1994). "If you read this last sentence, it won't tell you anything": Postmodernism, selfreferentiality, and The Stinky Cheese Man. Children's Literature Association Quarterly 19(1), 32-34. https://doi.org/10.1353/chq.0.0989

Tan, S. (2006). The arrival. Scholastic.

The witchball. (2005). In A. Carter (Ed.), Angela Carter's book of fairy tales (pp. 308-9). Virago.

Winant, J. (2015). The new title. In D. Fuss \& W. A. Gleason (Eds.), The pocket instructor: Literature: 101 exercises for the college classroom (pp. 37-9). Princeton University Press.

How to cite this paper:

Morris-O'Connor, D.A. (2021). Teaching Picturebooks in First Year Literature Courses. Journal of Literary Education, (4), 216-238. https://doi.org/10.7203/JLE.4.21025 